\title{
MENINGKATKAN KEMAMPUAN KOMUNIKASI MATEMATIS SISWA DALAM MENYELESAIKAN SOAL CERITA MELALUI PENDEKATAN PEMECAHAN MASALAH
}

\author{
Karlimah (arli.karlimah@gmail.com) \\ Dania Fuji Lestari \\ PGSD Universitas Pendidikan Indonesia Kampus Tasikmalaya
}

\begin{abstract}
ABSTRAK
Tujuan dari penelitian ini adalah untuk mengembangkan rencana pembelajaran dan menggambarkan pelaksanaan dan hasil belajar siswa melalui pendekatan pemecahan masalah untuk meningkatkan kemampuan komunikasi siswa dalam memecahkan masalah uji kasus matematika. Sebuah model penelitian tindakan kelas digunakan dan dilaksanakan pada bulan April 2010 di SDN 1 di Desa Saguling, Kecamatan Baregbeg, Ciamis Regenc, Provinsi Jawa Barat. Pengumpulan data dilakukan dengan 3 siklus dari 28 siswa kelas IV dan guru bertindak sebagai peneliti studi. Instrumen penelitian terdiri format penilaian RPP, format pengamatan kegiatan mengajar dan kegiatan belajar, lembar kerja siswa dan tes. Data dianalisis menggunakan metode triangualation, saturasi, dan akal sehat. Hasil penelitian menunjukkan bahwa pendekatan pemecahan masalah matematika adalah salah satu alternatif untuk meningkatkan kemampuan komunikasi siswa dalam memecahkan kasus uji matematika. Dalam rangka meningkatkan kemampuan komunikasi matematika siswa, disarankan untuk menggunakan pendekatan masalah Polya. Demikian pula , uji evaluasi harus mengandung aspek yang menunjukkan ide-ide matematika dalam bentuk gambar, menghubungkan gambar ke kalimat dan menyelesaikan proses algoritma.
\end{abstract}

Kata kunci: komunikasi matematika, pemecahan masalah pendekatan, uji kasus

\begin{abstract}
The objective of the study were to develop learning plan and describe the implementation and results of student learning through problem-solving approach in order to improve the communication skills of students in solving mathematical case test problems. A model of classroom action research was used and held in April 2010 at SDN 1 located at Saguling Village, District of Baregbeg, Ciamis Regenc, West Java Province. Data collection was conducted in 3 cycles out of 28 fourth grade students and a teacher who acts as a reseacher of the study. Research instrument consisted of assessment format of lesson plan, format observation of teaching activities nd learning actvities, student worksheet and test. Data were analyzed using a triangualation method, saturation, and common sense. The result revealed that the mathematical problem solving approach was one of alternatives to improve the communication skills of students in solving mathematical case test. In order to improve students' mathematical communication skills, it is advisable to use Polya problem solving approach. Similarly, evaluation test should contain aspects that demonstrate mathematical ideas in the form of images, linking images to the sentences and complete the process of the algorithm.
\end{abstract}

Keywords: case test, mathematical communication, problem solving approach 
Salah satu tujuan pembelajaran matematika adalah "mengomunikasikan gagasan dengan simbol, tabel, diagram, atau media lain untuk memperjelas keadaan atau masalah" (Depdiknas, 2006: 417). Kemampuan komunikasi matematis siswa perlu mendapat perhatian untuk dikembangkan dan diajarkan di Sekolah Dasar karena kemampuan siswa mengomunikasikan gagasan dalam bentuk simbol, tabel, diagram, atau media lainnya akan memperjelas informasi yang disampaikan. Namun, berdasarkan hasil diskusi dengan guru Sekolah Dasar Negeri 1 Saguling, kenyataannya siswa mempunyai masalah dalam mengerjakan soal cerita terutama pada saat mengomunikasikannya ke dalam bentuk tulisan. Siswa harus terus menerus dibimbing oleh guru untuk menyelesaikan soal cerita. Rendahnya kemampuan komunikasi siswa, tidak terlepas dari proses pembelajaran matematika yang dilakukan di kelas. Kebanyakan guru memili metode ceramah dalam mengajar matematika. Akibatnya siswa mengalami kesulitan dalam menyelesaikan soal cerita apabila tidak mendapat bimbingan langsung dari guru. Ketika jawaban telah ditemukan siswa pun cenderung kurang mengerti dengan jawaban mereka. Berdasarkan hasil tes awal mengenai kemampuan komunikasi siswa dalam menyelesaikan soal cerita, sebagian besar siswa belum mempunyai kemampuan komunikasi matematika. Hal ini ditunjukkan dengan rendahnya nilai ratarata tes awal siswa sebelum dilakukan pembelajaran dengan pendekatan pemecahan masalah matematika yaitu sebesar 50,40. Berdasarkan permasalahan tersebut, guru kelas IVB SDN 1 Saguling sebagai peneliti berupaya untuk mengatasi permasalahan siswa dalam menyelesaikan soal cerita. Sehubungan dengan hal tersebut, dilakukan penelitian berbasis tindakan kelas dengan melakukan suatu perubahan dalam pembelajaran untuk meningkatkan kemampuan komunikasi matematis siswa dalam menyelesaikan soal cerita. Salah satu perubahan yang dilakukan adalah menggunakan pendekatan pemecahan masalah matematika. Pendekatan pembelajaran tersebut menekankan pengalaman belajar melalui pemahaman isi dan maksud soal, perencanaan penyelesaian soal, pelaksanaan penyelesaian soal, dan pemeriksaan hasil penyelesaian soal.

Penelitian berbasis tindakan kelas ini bertujuan untuk mengetahui bagaimana meningkatkan kemampuan komunikasi matematis siswa dalam menyelesaikan soal cerita melalui pendekatan pemecahan masalah matematika di kelas IV Sekolah Dasar Negeri 1 Saguling Kecamatan Baregbeg Kabupaten Ciamis. Penelitian ini bertujuan untuk mengembangkan perencanaan serta mendeskripsikan pelaksanaan dan hasil belajar siswa melalui pendekatan pemecahan masalah untuk meningkatkan kemampuan komunikasi matematis siswa dalam menyelesaikan soal cerita.

Menurut Surya (2004:17), pembelajaran ialah suatu proses yang dilakukan oleh individu untuk memperoleh suatu perubahan perilaku yang baru secara keseluruhan, sebagai hasil dari pengalaman individu dalam interaksi dengan lingkungan. Berkaitan dengan itu, mata pelajaran matematika di sekolah dasar memiliki tujuan agar peserta didik memiliki kemampuan (1) memahami konsep matematika, menjelaskan keterkaitan antar konsep, dan mengaplikasikan konsep atau algoritma secara luwes, akurat, dan efisien, serta tepat dalam pemecahan masalah; (2) menggunakan penalaran pada pola dan sifat, melakukan manipulasi matematika dalam membuat generalisasi, menyusun bukti, atau menjelaskan gagasan dan pernyataan matematika; (3) memecahkan masalah yang meliputi kemampuan memahami masalah, merancang model matematika, menyelesaikan dan menafsirkan solusi yang diperoleh; 4) mengomunikasikan gagasan dengan simbol, tabel, diagram, atau media lain untuk memperjelas keadaan atau masalah; dan 5) memiliki sikap menghargai kegunaan matematika dalam kehidupan, yaitu memiliki rasa ingin tahu, perhatian dan minat dalam mempelajari matematika, serta sikap ulet dan percaya diri dalam pemecahan masalah (Depdiknas, 2006). 
Ruang lingkup mata pelajaran matematika pada satuan pendidikan SD/MI meliputi aspekaspek bilangan, geometri dan pengukuran, dan pengolahan data (Depdiknas, 2006). Sementara karakteristik siswa Sekolah Dasar memiliki pertumbuhan dan perkembangan yang relevan dengan perubahan struktur dan fungsi karakteristik. Menurut Piaget sebagaimana dikutip Mulyasa (2009:51) tahap perkembangan kognitif siswa sekolah dasar meliputi tahap sensorimotorik yaitu sejak lahir hingga usia dua tahun, tahap pra-operasional yaitu antara usia 2-7 tahun, tahap operasi nyata antara usia 7-11 tahun, dan tahap operasi formal yaitu antara usia 11 tahun dan seterusnya. Berdasarkan teori perkembangan kognitif individu dari Piaget, maka siswa kelas IV SD berada pada tahap operasi nyata (operasional konkret). Sehubungan dengan hal itu, maka pembelajaran matematika yang dilaksanakan di kelas IV harus diupayakan menggunakan media/alat peraga untuk membantu proses belajar siswa, di antaranya dengan menggunakan benda-benda konkret maupun gambar-gambar untuk memudahkan siswa dalam memahami serta menemukan konsep matematika yang mereka pelajari.

Harapan dari pembelajaran matematika yang memberikan fasilitas belajar sesuai dengan karakteristik siswa dapat menjadikan siswa memiliki kemampuan matematis, termasuk kemampuan komunikasi matematis. Komunikasi matematika adalah proses menyatakan dan menafsirkan gagasan matematika secara lisan, tertulis atau mendemonstrasikannya. Jadi siswa dikatakan mampu berkomunikasi dalam matematika jika mampu menyatakan dan menafsirkan gagasan matematika secara lisan, tertulis atau mendemonstrasikannya (Istiqomah, 2007: 30). Masih menurut Istiqomah, secara lebih terinci, komunikasi matematis adalah (1) menghubungkan benda nyata, gambar, dan diagram ke dalam ide matematika; (2) menjelaskan ide, situasi dan relasi matematik, secara lisan atau tulisan dengan benda nyata, gambar, grafik dan aljabar; (3) menyatakan peristiwa sehari-hari dalam bahasa atau simbol matematik; (4) mendengarkan, berdiskusi, dan menulis tentang matematika; dan (5) membaca dengan pemahaman suatu presentasi matematika tertulis.

Indikator kemampuan komunikasi matematis tersebut kemudian dikembangkan sebagai dasar penelitian ini. Indikator komunikasi matematis yang digunakan adalah menunjukkan ide matematik yang terdapat dalam soal cerita (esai) secara tulisan ke dalam bentuk gambar, menghubungkan gambar ke dalam kalimat matematika, dan menjelaskan penyelesaian algoritma matematika.

Soal cerita matematika ialah soal mengenai penerapan dari konsep matematika dengan masalah kehidupan sehari-hari (Iqsan, 2008). Kemampuan menyelesaikan masalah soal cerita merupakan kemampuan untuk melakukan penyelesaian masalah yang dimulai dari mengidentifikasi masalah (apa yang ditanyakan), mencari informasi apa yang diketahui, membuat operasi yang sesuai dengan menuliskan kalimat matematikanya, menyelesaikan kalimat matematika, diakhiri dengan pemeriksaan jawaban yang diperolehnya. Tujuan pemberian soal cerita adalah agar setelah proses pembelajaran berlangsung siswa dapat menerapkan konsep-konsep matematika yang telah dipelajarinya untuk menyelesaikan masalah yang biasa timbul dalam kehidupan sehari-hari.

Konten yang digunakan dalam soal cerita dalam penelitian ini adalah tentang pecahan, untuk siswa kelas IV SD. Standar kompetensi pembelajaran bilangan pecahan adalah menggunakan pecahan dalam pemecahan masalah. Kompetensi pembelajaran bilangan pecahan yaitu mengembangkan kemampuan operasi hitung bilangan pecahan dalam soal yang unik, misalnya dalam bentuk soal cerita. Pecahan merupakan bagian dari keseluruhan, bagian dari suatu daerah, bagian dari suatu benda atau bagian dari suatu himpunan. Menurut Kennedy sebagaimana dikutip oleh Sukayati (2003), makna pecahan muncul dari situasi-situasi: (1) pecahan sebagai bagian yang 
berukuran sama dari yang utuh atau keseluruhan, (2) pecahan sebagai bagian dari kelompokkelompok yang beranggotakan sama, dan (3) pecahan sebagai perbandingan.

Fasilitas pengembangan kemampuan komunikasi matematis tersebut dilaksanakan dalam pembelajaran matematika melalui pendekatan pemecahan masalah matematika. Pendekatan pemecahan masalah adalah suatu cara yang digunakan oleh guru dalam pembelajaran yang memberikan kesempatan kepada siswa untuk menyadari masalah, menelaah, menganalisis masalah, merumuskan masalah, mengkaji alternatif pemecahan masalah, dan mengkaji ketepatan pelaksanaan dan pemilihan alternatif penyelesaian masalah (Iqsan, 2008: 18).

Pendekatan pemecahan masalah disebut juga sebagai suatu pendekatan pembelajaran yang menuntut siswa untuk berpikir tingkat tinggi di mana siswa diberikan soal-soal untuk diselesaikan. Beberapa jenis masalah yang dapat digunakan dalam pembelajaran dengan pendekatan pemecahan masalah adalah masalah translasi, masalah aplikasi, masalah proses, dan masalah teka-teki (Hudoyo \& Sutawidjaya, 1997: 191).

Menurut Polya sebagaimana dikutip oleh Suherman, et al, (2003: 91), solusi soal pemecahan masalah memuat empat langkah penyelesaian, yaitu (1) memahami masalah, (2) merencanakan penyelesaian, (3) menyelesaikan masalah sesuai dengan rencana, dan (4) melakukan pengecekan kembali terhadap semua langkah yang telah dikerjakan. Pendekatan pemecahan masalah dalam penelitian ini dilaksanakan bersamaan dengan membuat gambar. Hal tersebut disebabkan salah satu indikator keberhasilan kemampuan komunikasi matematis yang akan dikembangkan dalam penelitian ini adalah menjelaskan ide, situasi dan relasi matematika, secara lisan atau tulisan dengan benda nyata, gambar, grafik dan aljabar. Gambar yang dibuat pun tidak harus terlalu sempurna atau terlihat bagus. Hal yang perlu digambar adalah bagian-bagian terpenting yang diperkirakan dapat memperjelas informasi yang terkandung dalam soal cerita.

\section{METODE}

Penelitian ini menggunakan penelitian tindakan kelas (PTK) model Kemmis \& Mc. Taggart (Hopkins, 1993) yang meliputi tiga siklus. Subjek penelitian adalah siswa kelas IVB Sekolah Dasar Negeri 1 Saguling Desa Saguling Kecamatan Baregbeg Kabupaten Ciamis yang berjumlah 28 siswa, yang terdiri atas 8 orang siswa laki-laki dan 20 orang siswa perempuan. Dalam penelitian ini guru berperan sebagai peneliti.

Siklus I dilaksanakan pada hari Rabu, 21 April 2010, Siklus II dilaksanakan pada hari Senin, 26 April 2010, dan Siklus III dilaksanakan pada hari Rabu, 28 April 2010. PTK ini dilaksanakan dalam tiga tahapan yaitu (1) tahap perencanaan yaitu membuat RPP, menyiapkan LKS, soal evaluasi, media, dan sumber pembelajaran, selanjutnya observer menilai RPP dengan menggunakan format penilaian RPP, (2) tahap pelaksanaan dan observasi, adalah rangkaian pembelajaran yang terdiri atas kegiatan awal, kegiatan inti, dan kegiatan akhir, serta pelaksanaan observasi terhadap aktivitas guru dan siswa selama pembelajaran, dan (3) tahap refleksi dilakukan dengan menganalisis dan merefleksi kemampuan guru dalam merancang RPP dan melaksanakan pembelajaran, ditinjau dari aktivitas guru dan siswa.

Instrumen penelitian mencakup format penilaian Rencana Pelaksanaan Pembelajaran (RPP), format observasi aktivitas guru, dan format observasi aktivitas siswa dalam kelompok. Instrumen lainnya adalah: (i) Lembar Kerja Siswa (LKS) dan soal evaluasi tentang menyelesaikan soal cerita terkait penjumlahan pecahan untuk digunakan pada Siklus I, (ii) LKS dan soal evaluasi tentang menyelesaikan soal cerita terkait pengurangan pecahan pada Siklus II, dan (iii) LKS dan soal evaluasi tentang menyelesaikan soal cerita terkait operasi hitung campuran pecahan (penjumlahan 
dan pengurangan) pada Siklus III. Data yang terkumpul pada setiap siklus sampai akhir penelitian dianalisis dengan menggunakan triangulasi, saturasi (kejenuhan), dan common sense.

\section{HASIL DAN PEMBAHASAN}

Pada kegiatan tes awal, ditemukan bahwa siswa tidak mampu menunjukkan ide matematika yang ada dalam soal cerita ke dalam bentuk gambar. Siswa juga mempunyai masalah dalam menghubungkan gambar yang telah siswa buat ke dalam kalimat matematika kemudian menyelesaikannya secara algoritmik (operasi hitung).

\section{Perencanaan Pembelajaran}

Konten yang digunakan dalam penelitian ini adalah tentang pecahan. Konten tersebut dipelajari di kelas IV semester II. Skenario pembelajaran disusun dalam waktu 3 jam pelajaran ( $3 \mathrm{x}$ 35 menit). Langkah-langkah pembelajaran dirancang untuk setiap siklus adalah sebagai berikut. Kegiatan awal secara garis besar langkah-langkahnya adalah guru mengkondisikan siswa ke dalam situasi belajar yang kondusif, melakukan apersepsi, dan menyampaikan tujuan pembelajaran.

Langkah-langkah kegiatan inti secara garis besar adalah: (i) guru mengingatkan tentang konsep penjumlahan bilangan pecahan (Siklus I), pengurangan bilangan pecahan (Siklus II), operasi hitung campuran bilangan pecahan (penjumlahan dan pengurangan) bilangan pecahan (SiklusIII), (ii) memberikan contoh cara menyelesaikan soal cerita dengan menggunakan pendekatan pemecahan masalah matematika, (iii) siswa dalam kelompok belajar mengerjakan LKS yang telah disediakan guru, (iv) menyimpulkan pembelajaran. Kegiatan akhir kegiatan yang akan dilaksanakan yaitu: memberi soal tes akhir sesuai konten yang dipelajari untuk setiap siswa, kemudian memeriksa bersama siswa, menutup pelajaran, serta memberi tindak lanjut.

\section{Pelaksanaan Pembelajaran}

Pelaksanaan pembelajaran pada Siklus I, Siklus II, dan Siklus III menunjukkan adanya kesesuaian dengan kebutuhan. Siswa terlihat lebih aktif belajar menyelesaikan soal cerita. Hal tersebut dilihat pada saat proses pembelajaran dan mengerjakan LKS. Pelaksanaan pembelajaran pada Siklus I, Siklus II, dan Siklus III secara konsep tidak berbeda jauh, yaitu melaksanakan pembelajaran dengan menjelaskan dan memberikan fasilitas belajar, menyelesaikan soal cerita dengan menggunakan pendekatan pemecahan masalah matematika. Siswa secara berkelompok mengerjakan LKS, dan secara individu mengerjakan soal (evaluasi) tes akhir.

\section{Refleksi}

\section{Siklus I}

Ditinjau dari aspek Rencana Pelaksanaan Pembelajaran (RPP), maka metode pembelajaran yang digunakan belum berpusat pada siswa dan belum dapat meningkatkan kemampuan komunikasi matematis siswa, sehingga harus ditambah lagi dengan menggunakan metode demonstrasi dan variasi media belajar tentang pecahan.

Ditinjau dari aspek pelaksanaan pembelajaran, maka terlihat bahwa (i) guru kurang membantu/membimbing siswa menyelesaikan soal cerita dengan menggunakan pendekatan pemecahan masalah matematika, (ii) dalam pengelolaan kelas guru tidak memberi kesempatan pada setiap kelompok untuk aktif belajar dan melaporkan hasil belajarnya, (iii) guru belum terampil memotivasi siswa untuk belajar dan menjawab pertanyaan eksplorasi maupun elaborasi dalam pelaksanaan pembelajaran. Demikian pula dalam menggunakan media dan alat peraga, efisiensi dan 
efektivitas dalam mengelola waktu dan kegiatan belajar serta menyimpulkan hasil pembelajaran, (iv) sebagian siswa belum menunjukan motivasi yang tinggi untuk belajar dan menjawab pertanyaan guru untuk menggali pengetahuan awal siswa.

Ditinjau dari aspek hasil belajar siswa, siswa masih mengalami kesulitan dalam menunjukkan ide, situasi, dan relasi matematik secara tulisan dengan gambar (K1), menghubungkan gambar ke dalam kalimat matematika (K2), dan menjelaskan penyelesaian algoritma matematika (K3).

\section{Siklus II}

Ditinjau dari aspek perencanaan pembelajaran, tampaknya langkah-langkah pembelajaran kurang memberi kesempatan meningkatkan kemampuan komunikasi matematis siswa dalam menyelesaikan soal cerita melalui pendekatan pemecahan masalah matematika dalam bentuk mengerjakan soal cerita maupun mengomunikasikan hasilnya di depan kelas. Ditinjau dari aspek pelaksanaan pembelajaran, kemampuan guru dalam memotivasi siswa belajar masih belum menunjukkan hasil yang optimal dalam hal eksplorasi maupun elaborasi diri.

Ditinjau dari aspek hasil belajar siswa, kenaikan nilai rata-rata pada aspek menghubungkan gambar ke dalam kalimat matematika dan menyelesaikan proses matematisasi masih kurang. Dalam mengubah gambar ke dalam kalimat matematika mengalami kenaikan tidak terlalu besar yaitu 0,40.

\section{Siklus III}

Pada Siklus III dapat diidentifikasi terjadi peningkatan yang optimal dalam perencanaan pelaksanaan pembelajaran, aktivitas guru dalam pembelajaran serta aktivitas siswa dalam belajar (kelompok). Di samping itu, kemampuan komunikasi matematis siswa dalam menyelesaikan soal cerita telah meningkat.

\section{Hasil Pembelajaran}

Hasil pembelajaran yang dimaksud pada setiap siklus dapat dilihat pada Tabel 1.

Tabel 1. Kemampuan Komunikasi Matematika Siswa pada Tiap Siklus

\begin{tabular}{|c|c|c|c|c|c|c|c|c|c|c|c|c|}
\hline \multirow{2}{*}{ Nama Siswa } & \multicolumn{4}{|c|}{ Siklus I } & \multicolumn{4}{|c|}{ Siklus II } & \multicolumn{4}{|c|}{ Siklus III } \\
\hline & K1 & K2 & K3 & Nilai akhir & K1 & $\mathrm{K} 2$ & K3 & Nilai akhir & K1 & $\mathrm{K} 2$ & K3 & Nilai akhir \\
\hline (2) & (3) & (4) & (5) & (6) & (7) & (8) & (9) & (10) & (11) & (12) & (14) & (14) \\
\hline S.1 & 30 & 30 & 10 & 46,7 & 30 & 30 & 10 & 46,7 & 40 & 10 & 30 & 53,3 \\
\hline S.2 & 30 & 40 & 30 & 66,7 & 30 & 30 & 40 & 66,7 & 40 & 40 & 40 & 80 \\
\hline S. 3 & 40 & 40 & 30 & 73,3 & 30 & 30 & 40 & 66,7 & 40 & 50 & 40 & 86,7 \\
\hline S. 4 & 10 & 40 & 30 & 53,3 & 30 & 30 & 40 & 66,7 & 30 & 50 & 40 & 8 \\
\hline S.5 & 30 & 30 & 30 & 60 & 30 & 40 & 40 & 73,3 & 30 & 40 & 40 & 73,3 \\
\hline S. 6 & 30 & 40 & 40 & 73,3 & 40 & 40 & 30 & 73,3 & 30 & 40 & 40 & 73,3 \\
\hline S.7 & 40 & 40 & 30 & 73,3 & 40 & 30 & 30 & 66,7 & 50 & 40 & 50 & 93,3 \\
\hline S.8 & 30 & 30 & 10 & 46,7 & 30 & 10 & 30 & 46,7 & 40 & 30 & 10 & 53,3 \\
\hline S.9 & 30 & 40 & 40 & 73,3 & 30 & 40 & 30 & 66,7 & 40 & 40 & 40 & 80 \\
\hline S.10 & 30 & 10 & 30 & 46,7 & 30 & 30 & 10 & 46,7 & 40 & 30 & 10 & 53,3 \\
\hline S.11 & 30 & 10 & 30 & 46,7 & 50 & 30 & 30 & 73,3 & 40 & 40 & 40 & 80 \\
\hline S.12 & 30 & 10 & 30 & 46,7 & 30 & 30 & 30 & 60 & 30 & 30 & 30 & 60 \\
\hline S.13 & 30 & 40 & 30 & 66,7 & 30 & 30 & 30 & 60 & 30 & 30 & 40 & 66,7 \\
\hline S.14 & 30 & 10 & 10 & 33,3 & 40 & 10 & 10 & 40 & 30 & 30 & 10 & 46,7 \\
\hline
\end{tabular}


Tabel 1. Lanjutan

\begin{tabular}{|c|c|c|c|c|c|c|c|c|c|c|c|c|}
\hline \multirow{2}{*}{ Nama Siswa } & \multicolumn{4}{|c|}{ Siklus I } & \multicolumn{4}{|c|}{ Siklus II } & \multicolumn{4}{|c|}{ Siklus III } \\
\hline & K1 & K2 & $\mathrm{K} 3$ & Nilai akhir & K1 & K2 & K3 & Nilai akhir & K1 & K2 & K3 & Nilai akhir \\
\hline (2) & (3) & (4) & (5) & (6) & (7) & (8) & (9) & (10) & (11) & (12) & (14) & (14) \\
\hline S.14 & 30 & 10 & 10 & 33,3 & 40 & 10 & 10 & 40 & 30 & 30 & 10 & 46,7 \\
\hline S.15 & 30 & 30 & 10 & 46,7 & 30 & 10 & 30 & 46,7 & 30 & 30 & 10 & 46,7 \\
\hline S.16 & 30 & 30 & 40 & 66,7 & 40 & 40 & 30 & 73,3 & 40 & 50 & 40 & 86,7 \\
\hline S.17 & 30 & 40 & 40 & 73,3 & 40 & 40 & 30 & 73,3 & 50 & 50 & 40 & 93,3 \\
\hline S.18 & 40 & 40 & 40 & 80 & 50 & 40 & 30 & 80 & 40 & 50 & 40 & 86,7 \\
\hline S.19 & 30 & 30 & 10 & 46,7 & 30 & 10 & 30 & 46,7 & 30 & 40 & 30 & 66,7 \\
\hline S. 20 & 40 & 40 & 40 & 80 & 40 & 40 & 30 & 73,3 & 50 & 40 & 40 & 86,7 \\
\hline S.21 & 30 & 30 & 30 & 60 & 10 & 30 & 40 & 53,3 & 40 & 40 & 30 & 73,3 \\
\hline S.22 & 40 & 30 & 30 & 66,7 & 40 & 30 & 30 & 66,7 & 40 & 50 & 50 & 93,3 \\
\hline S.23 & 30 & 30 & 40 & 66,7 & 30 & 50 & 40 & 80 & 50 & 50 & 50 & 100 \\
\hline S.24 & 10 & 40 & 30 & 53,3 & 30 & 40 & 30 & 66,7 & 40 & 40 & 50 & 86,7 \\
\hline S. 25 & 10 & 40 & 30 & 53,3 & 40 & 40 & 40 & 80 & 50 & 50 & 50 & 100 \\
\hline S. 26 & 40 & 30 & 30 & 66,7 & 50 & 30 & 30 & 73,3 & 40 & 40 & 40 & 80 \\
\hline S. 27 & 30 & 30 & 30 & 60 & 50 & 50 & 40 & 93,3 & 50 & 50 & 50 & 100 \\
\hline S.28 & 30 & 30 & 30 & 60 & 30 & 10 & 10 & 46,7 & 30 & 40 & 40 & 73,3 \\
\hline $\begin{array}{l}\text { Jumlah yang } \\
\text { diperoleh }\end{array}$ & 840 & 880 & 810 & 1686,7 & 980 & 890 & 840 & 1806,7 & 1090 & 1120 & 1020 & 2153,3 \\
\hline $\begin{array}{l}\text { Nilai Rata- } \\
\text { Rata }\end{array}$ & 30 & 31,4 & 28,9 & 60,2 & 35,2 & 31,8 & 30 & 64,5 & 38,9 & 40 & 36,4 & 76,9 \\
\hline $\begin{array}{l}\text { Persentase } \\
\text { Keberhasilan }\end{array}$ & & & $60,7 \%$ & & & & $1,4 \%$ & & & & $2,1 \%$ & \\
\hline
\end{tabular}

\section{Keterangan:}

K1 : Menunjukkan ide matematik yang terdapat dalam soal cerita secara tulisan ke dalam bentuk gambar

K2 : Menghubungkan gambar ke dalam kalimat matematika

K3 : Menjelaskan penyelesaian algoritma matematika

\section{Hasil Proses pada Setiap Siklus}

Proses penelitian pada setiap siklus direkapitulasikan dalam Tabel 2.

Tabel 2. Rekapitulasi Persentase Hasil Penelitian pada Setiap Siklus

\begin{tabular}{lccc}
\hline \multicolumn{1}{c}{ Uraian } & Siklus I & Siklus II & Siklus III \\
\hline Perolehan nilai RPP & $68 \%$ & $88 \%$ & $100 \%$ \\
Perolehan nilai aktivitas guru dalam mengajar & $74 \%$ & $92,6 \%$ & $96,3 \%$ \\
Nilai aktivitas siswa belajar dalam kelompok & $67,8 \%$ & $88,2 \%$ & $94,2 \%$ \\
\hline
\end{tabular}

\section{KESIMPULAN DAN SARAN}

Rencana pelaksanaan pembelajaran untuk meningkatkan kemampuan komunikasi matematika siswa dalam menyelesaikan soal cerita melalui pendekatan pemecahan masalah matematika bahwa (i) siswa dapat menunjukkan ide, situasi, dan relasi matematik secara tulisan dengan gambar, siswa dapat menghubungkan gambar ke dalam kalimat matematika, siswa menjelaskan penyelesaian algoritma matematika serta siswa dapat memecahkan masalah yang 
terdapat dalam soal cerita, (ii) terdapat langkah-langkah menyelesaikan soal cerita dengan menggunakan strategi menurut Polya yaitu tahap memahami masalah, merencanakan strategi, melaksanakan strategi, dan memeriksa kembali.

Pembelajaran untuk meningkatkan kemampuan komunikasi matematika siswa dengan menggunakan pendekatan pemecahan masalah matematika yaitu guru mengajarkan cara menyelesaikan soal cerita dengan menggunakan tahapan-tahapan menurut Polya yang terdiri atas 4 tahap yaitu tahap memahami masalah, tahap merencanakan strategi, tahap melaksanakan sesuai dengan strategi, dan tahap memeriksa kembali. Siswa ditugaskan untuk mengerjakan LKS berupa soal cerita tentang bilangan pecahan secara berkelompok, dan evaluasi tentang soal cerita secara individu.

Berdasarkan perencanaan, dan pelaksanaan pembelajaran dengan menggunakan pendekatan pemecahan masalah matematika maka diperoleh hasil kemampuan komunikasi matematika siswa untuk setiap siklus. Siklus I nilai rata-rata yang diperoleh 60,2 dengan persentase keberhasilan $60,7 \%$, siklus II nilai rata-rata yang diperoleh 64,5 dengan persentase keberhasilan $71,4 \%$, dan siklus III nilai rata-rata yang diperoleh 76,9 dengan persentase keberhasilan $82,1 \%$.

Untuk meningkatkan kemampuan komunikasi matematis siswa dalam menyelesaikan soal cerita (dalam perencanaan dan pelaksanaan pembelajaran) hendaknya menggunakan pendekatan pemecahan masalah dengan menggunakan tahapan-tahapan menurut Polya yaitu tahap memahami masalah, merencanakan strategi, melaksanakan strategi, dan memeriksa kembali. Soal evaluasi harus mengandung aspek-aspek kemampuan komunikasi matematika yaitu aspek menunjukkan ide matematik yang terdapat dalam soal cerita secara tulisan ke dalam bentuk gambar serta aspek menghubungkan gambar ke dalam kalimat matematika dan menyelesaikan proses algoritma.

\section{REFERENSI}

Departemen Pendidikan Nasional, (2006). Standar kompetensi dasar KTSP 2006. Jakarta: Depdiknas.

Hopkins, D. (1993). A Teacher's guide to classroom research. Buckingham-Philadelphia: Open University Press..

Hudoyo, H. \& Sutawidjaya, A. (1997). Matematika. Jakarta: Departemen Pendidikan dan Kebudayaan Direktorat Jendral Pendidikan Tinggi Bagian Proyek Pengembangan Pendidikan Guru Sekolah Dasar.

Iqsan, I. (2008). Pendekatan pemecahan masalah dalam meningkatkan kemampuan menyelesaikan soal cerita. FIP PGSD UPI. Bandung: Tidak Diterbitkan.

Istiqomah, N.(2007).Upaya meningkatkan kemampuan komunikasi matematika siswa kelas IV SD negeri Sekaran 2 pada materi pokok kelipatan persekutuan terkecil (KPK) dan pecahan dengan menggunakan pembelajaran kurikulum berbasis kompetensi (KBK) bercirikan pendayagunaan alat peraga dan pendampingan tahun pelajaran 2006/2007. Diambil pada tanggal 16 Januari 2010 dari http://digilib.unnes.ac.id/gsdl/collect/skripsi/index/assoc/ HASH01a1/01cb6433.dir/doc.pdf.

Mulyasa, E. (2009). Implementasi kurikulum tingkat satuan pendidikan. Jakarta: Bumi Aksara.

Suherman, E. et al. (2003). Strategi pembelajaran matematika kontemporer. Bandung: Universitas Pendidikan Indonesia.

Sukayati. (2003). Pecahan. Yogyakarta: Tim PPG Matematika.

Surya, M. (2004). Psikologi pembelajaran dan pengajaran. Bandung: Pustaka Bani Quraisy. 